\title{
INDICADORES ÉTNICOS EN LA ANDALUCÍA PRERROMANA
}

\author{
ETHNIC MARKERS IN PRE-ROMAN ANDALUSIA
}

por

\author{
JOSE LUIS ESCACENA CARRASCO
}

RESUMEN El análisis de las características principales observadas, a través del registro arqueológico, en los territorios andaluces ocupados por los pueblos prerromanos permite sopesar el valor de cada una de ellas como baremo para establecer barreras étnicas entre unas comunidades y otras. Se reflexiona aquí sobre cuáles sean los elementos más apropiados para dibujar esas fronteras, así como sobre los que no proporcionan bases claras para encontrar diferencias en el comportamiento cultural. Los primeros afectan al campo animológico, los segundos a la tecnología.

\begin{abstract}
The analysis of the main features of the Andalusian territories occupied by preroman peoples, studied through the archaeological record, allows us to asses their value in establishing ethnic barriers among different communities. We reflect on which are the most suitable elements for the drawing of these ethnic frontiers and on those that do not provide clear bases to determine differences in the cultural behaviour. The firts ones affect to the spirit, the latter to the technology.
\end{abstract}

\section{INTRODUCCION}

El tema fundamental del presente trabajo recoge una preocupación personal por contribuir a la definición de los rasgos culturales que permitan dibujar las fronteras étnicas entre las comunidades prerromanas de Andalucía. Esta meta ha tenido cierta tradición en la historiografía relativa a los pueblos protohistóricos hispanos, pero recientemente ha experimentado un nuevo auge (Chapa y Pereira, e.p.); de manera que no son pocas las reuniones científicas y las publicaciones en las que se ha tomado dicho o parecido fin como centro aglutinador de las mismas: Simposi Internacional "Els Orígens del Món Ibèric" (Barcelona-Empúries, 1977), publicado en la revista Ampurias 38-40 (1976- 
78); La Baja Epoca de la Cultura Ibérica, Madrid 1979; "La Cultura Ibérica”. Homenaje a Domingo Fletcher Valls, en la revista Varia III (1984); Iberos. Primeras Jornadas Arqueológicas sobre el Mundo Ibérico / Jaén, 1985, que vieron la luz en Jaén en 1987; Fronteras. Arqueología Espacial 13 (Teruel, 1989), Teruel 1989; I Congreso de Paletnología de la Península Ibérica (Madrid, 1989), aún en prensa; Simposi Internacional d'Arqueologia Ibèrica. Fortificacions. La problemàtica de l'ibèric ple: (segles IV-III a.C.), (Manresa, 1990), Manresa 1991; Los Celtas en la Península Ibérica, Revista de Arqueología (n.ำ especial); etc. Para el mundo protohistórico meridional, M. Almagro-Gorbea (1982) reflexionó ya sobre la posibilidad de utilizar las cajas funerarias de piedra y las cámaras sepulcrales que aparecen en Andalucía oriental como evidencia arqueológica específica del complejo bastetano, mientras los trabajos de Pereira (1989b), entre otros, han puesto el dedo en la llaga en lo concerniente a las similitudes y diferencias entre la alta y la baja Andalucía por lo que respecta al mundo de la muerte. Recientemente, T. Chapa (e.p.) se ha preocupado por distinguir en la necrópolis de Villaricos cuáles sean las características peculiares de los ritos funerarios indígenas y cuáles las de la población púnica. De forma paralela, los estudios llevados a cabo desde los centros universitarios y otras instituciones de Jaén y Granada, por una parte, y de Sevilla, Cádiz, Córdoba y Huelva, por otra, han proyectado estas miras hacia otros campos distintos del de la muerte, y han logrado de alguna forma empezar a individualizar, a través de la impronta arqueológica que dejaron, una serie de conjuntos de poblaciones que, a tenor de lo que nos transmitieron los geógrafos e historiadores grecolatinos, dispusieron de las suficientes diferencias entre sí como para recibir etnónimos distintos.

Sería una pretensión inabarcable intentar aquí, en el marco de un simple artículo, resolver de una vez por todas el problema de la delimitación de las etnias prerromanas andaluzas, sobre todo $-\mathrm{y}$ especialmente- porque no existe consenso aún entre los historiadores y arqueólogos sobre cuáles sean los caracteres que deban utilizarse en esa tarea, y porque, aún si hubiese acuerdo, la movilidad de esos límites durante el devenir histórico exigiría ir dibujándolos al menos una vez por cada uno de los cinco siglos transcurridos entre la desaparición de Tartessos y el cambio de Era. La primera razón obliga desde luego a no abordar aún la confección de esa paleocartografía aludida en la segunda, ya que ni siquiera se han puesto de acuerdo los especialistas a la hora de seleccionar campos específicos (animológicos o tecnológicos por ejemplo) para usarlos como base diferencial de las distintas culturas. Esta liberación es en realidad un aplazamiento y, en consecuencia, un compromiso para trabajos futuros, pero permitirá conseguir en el presente dos objetivos fundamentales: por una parte, introducir reflexiones y puntos de vista que matizan en cierta medida la metodología empleada en el análisis histórico y el modo de ver y de presentar la documentación arqueológica; por otra, y dado que la meta se refiere a Andalucía, trabajar en un mundo culturalmente fronterizo entre las comunidades hispanas ibéricas y las no ibéricas, con las posibilidades de contraste que esto ofrece para facilitar el acceso al conocimiento de los pueblos anterromanos de la Península. Surge así la obligación, por aquello de que no traiciona quien advierte, de dar explicación preliminar a unos cuantos criterios teóricos en los que se basa el presente estudio, que en gran medida conducen a los resultados que con él se consiguen.

Mayoritariamente, el conocimiento de los grupos humanos de la segunda Edad del Hierro de la Península Ibérica en general, y de Andalucía en particular, ha sido abordado desde las fuentes arqueológicas; porque los escritos relativos a esas comunidades llevados a cabo en la Antigüedad son por lo general escasos e incompletos, y, en opinión de muchos historiadores, bastante tendenciosos. Esta circunstancia elimina como objeto de estudio un gran porcentaje de los aspectos culturales que se podrían conocer de cualquiera de dichas etnias, ya que, como bien han recordado muchos autores preocupados por la formación metodológica de los arqueólogos, y recientemente por ejemplo M.A. Querol (1991: 19-22) con motivo del estudio del registro paleolítico, los yacimientos proporcionan una 
parte minoritaria de lo que constituyó la cultura material de una sociedad' en su totalidad. Por lo demás, una visión de la arqueología entendida como ciencia para el estudio de los restos materiales de las culturas del pasado, y que convertía por ello en destino lo que debía ser más bien ruta, ha contribuido durante años a presentar un panorama uniforme donde tal vez hubo diferencias, sobre todo porque la tecnología de las gentes antiguas se tenía como baremo exclusivo a partir del cual definir su etnicidad; y es bien sabido, gracias a múltiples trabajos etnográficos, que la tecnología tiene la capacidad de trascender fronteras lingüísticas, políticas, geográficas y étnicas.

En contraposición a estas directrices, la filiación de los distintos pueblos prerromanos podría deducirse a partir de cuestiones referidas a las pautas conductuales animológicas más que desde la cultura material, y ésta a su vez servir de senda por la que discurrir hacia la definición de las características de cada comunidad. Desde este punto de vista, la lengua, la religión, los ritos funerarios, los sistemas totémicos, la organización familiar y social, las formas de posesión del territorio histórico, la conciencia de pueblo plasmada en los etnónimos autoimpuestos, los sistemas económicos, etc. se convierten en la carta de presentación de los pueblos, por encima desde luego de la tecnología, que no es más que un mecanismo material de adaptación a unas circunstancias geográficas determinadas y a un nicho ecológico concreto (Harris, 1987: 8-9). Es entonces cuando, invirtiendo el argumento usado por muchos historiadores según el cual las fuentes escritas antiguas no responden a la verdad cuando los datos arqueológicos las contradicen, los restos materiales pasan a ser interpretados a través de lo que esos textos afirman sobre la comunidad a la que pertenecieron; de manera que la información literaria reunida por los tratadistas griegos y romanos acaba por no ofrecer mucha contradicción con las conclusiones deducidas hoy del registro arqueológico.

Todas estas consideraciones teóricas y metodológicas son las que en el fondo permitirán observar en los grupos humanos de la Andalucía prerromana una homogeneidad (la tecnología descargada del más mínimo significado simbólico) bajo la que existió -oculta a la mirada de muchos arqueólogosuna heterogeneidad espiritual o animológica que sustentó las divisiones étnicas de las que los historiadores y geógrafos grecolatinos dieron buena fe.

\section{ELEMENTOS NO DIFERENCIADORES}

Si se rastrea en una visión restrospectiva, a partir de época romana, hasta cuándo tiene continuidad en Andalucía el poblamiento humano de muchas de sus comarcas, se puede llegar a establecer una clara barrera en los inicios del Bronce Final (Abad, 1979: 177). Antes se desarrollaron culturas que, denominadas por los especialistas con distintos nombres según la cronología y área geográfica que ocuparan (Argar, Horizonte de las Cistas de Huelva, Bronce del Bajo Guadalquivir, Bronce Tardío, etc.), no parecen ser con claridad el origen de muchos de los grupos de población que darían origen a las comunidades que los fenicios encontraron al colonizar a partir del siglo VIII a.C. las costas meridionales de la Península Ibérica. Generalizar de esta forma un proceso de ocupación del territorio tan complejo no responde seguramente a la realidad histórica de cada parcela concreta de Andalucía; porque a nivel local pueden defenderse continuidades poblacionales desde el Calcolítico muchas veces. Pero permite al menos disponer de una barrera cronológica inicial a partir de la cual investigar las raíces de las etnias prerromanas, ya que en amplias regiones del mediodía español es fácil detectar una ruptura demográfica -y por tanto cultural- entre los grupos del Bronce Pleno y los del Bronce Final precolonial. Una cura en salud sobre esta última y arriesgada afirmación quedaría matizada puntualizando que esta discontinuidad está desde luego más claramente marcada en la documentación arqueo- 
lógica de Andalucía occidental (Escacena y Belén, 1991: 24-26) que en la del Alto Guadalquivir o en la de la parte oriental de la región, donde se ha defendido que el Bronce Final es el resultado de la confluencia, sobre una base argárica depauperada, de factores de muy diversa índole y procedencia (Molina, 1978: 206-208). Esta dualidad de sustratos para una y otra partes de Andalucía hace abrigar la sospecha de que en la línea de partida del desarrollo de su Protohistoria, es decir, ya a finales de la Edad del Bronce, se puedan encontrar muchas de las explicaciones necesarias para comprender la bifurcación sustancial que afectará a las comunidades de los posteriores tiempos prerromanos.

En función de estas diferencias iniciales, que darán lugar sin duda a periodos formativos de alguna forma heterogéneos, los fenómenos que uniformizan el territorio andaluz en epoca protohistórica constituyen un lote de elementos tecnológicos que la arqueología viene estudiando cada vez con mayor precisión desde el siglo pasado, cuando ejercieron su labor pionera L. Siret y G. Bonsor entre otros: técnicas arquitectónicas y directrices urbanísticas, alfarería, metalurgia, etc.

\section{Casas y ciudades}

Por lo que respecta a la arquitectuta y al urbanismo, el sustrato precolonial muestra por lo general una casi total ausencia del segundo y una simplicidad clara de la primera. Las cabañas, por lo general aisladas unas de otras, esto es, sin formar manzanas, se disponen de forma aleatoria e irregular por el poblado. Abundan especialmente las de planta circular, como las encontradas por ejemplo en Acinipo, en la provincia de Málaga (Aguayo, y otros 1985: láms. III Y IV). Pero a partir de época orientalizante o primera Edad del Hierro se va a imponer paulatinamente la vivienda rectangular o cuadrada, fabricada claramente con paredes rectas que giran en ángulos de noventa grados. El origen de estos nuevos modelos arquitectónicos es evidentemente mediterráneo y extrapeninsular, venido de la mano de la colonización oriental. En algún caso, según ocurre en Montemolín (Marchena, Sevilla), se ha defendido que las primeras casas rectangulares corresponderían a colonos agrícolas instalados en el interior del territorio tartésico (Chaves y de la Bandera, 1991: 714). En otros, y mayoritariamente, se acepta que estas viviendas corresponderían a indígeneas aculturados, como se dice por ejemplo para las de Tejada y Huelva (Fernández Jurado, 1989: 173). De cualquiera de las maneras, parece demostrado que la paulatina extensión del uso de estas innovaciones permitió el desarrollo de una planificación urbana más organizada, con la delimitación cada vez más clara de manzanas de casas con accesos a calles trazadas a cordel, dando lugar en conjunto incluso a espacios destinados a edificios públicos. Puente Tablas, en la provincia de Jaén (Ruiz y Molinos, 1985, 1986 y 1988), y Tejada la Vieja, en la de Huelva (Fernández Jurado, 1987a y 1991: 56-58), constituyen claras muestras de estas nuevas y auténticas ciudades.

El calificativo urbano aplicado a éstos y a otros muchos emplazamientos se deduce, más que de la planta de sus edificios, de ciertas divisiones internas de los mismos en habitaciones distintas con materiales arqueológicos también diversos, lo que sugiere la existencia de unas labores artesanales y de una división del trabajo propia de sociedades organizadas según las características de la vida civilizada.

Si bien esta consideración de enclaves urbanos ha sido puesta en duda o minimizada para alguna parte del territorio andaluz, el tartésico en concreto, con la defensa de un carácter más aldeano (González Wagner 1986a: 219-220 y 225. Idem, e.p. En contra: Bendala, 1989), lo cierto es que, por lo que se refiere a las cuestiones técnicas concernientes a la arquitectura, desde la primera Edad del Hierro Andalucía entera conoció la progresiva implantación del muro recto y, por consiguiente, de los edificios -fuesen o no viviendas propiamente dichas- de planta rectangular o cuadrada. Esta es una caracte- 
rística homogénea para todas las etnias prerromanas que habitaron el sur de España, cuyas gentes adoptaron para sí, por las evidentes ventajas que suponían en la organización interna de los poblados, los nuevos modelos de viviendas introducidos en el territorio por la colonización oriental.

No siempre la casa fue copiada en su estructura interna, más bien al contrario; de manera que en muchas ocasiones faltarán claras y abundantes divisiones en su interior, circunstancia que apunta la posibilidad de que la imitación y aceptación de las nuevas normas constructivas no llevara aparejada una paralela transformación de la vida desarrollada en ellas ni, menos aún, de la estructura parental de la familia que habitara en cada unidad doméstica.

La construcción de defensas para las ciudades es también similar para la totalidad del territorio andaluz; porque las diferencias observadas entre unas y otras murallas responden más a una evolución cronológica que a distinciones sustentadas en las peculiaridades de cada pueblo. Otras veces, la diversidad se deriva de las posibilidades económicas de la comunidad, de su potencial bélico, de las características del territorio que controla, de las circunstancias de la política "internacional", de las directrices poliorcéticas de la época, del prestigio del núcleo de población, etc. (Fernández Jurado, 1991: 58-64. Ruiz, y otros 1991: 114-124). Pero no parece nunca posible, llegada la segunda Edad del Hierro, atribuir tal o cual tipo de defensas a un grupo humano concreto en función de la pertenencia mayoritaria de sus componentes a una etnia determinada.

\section{La vajilla cerámica}

Como elemento que, salvo excepciones, carecía de contenido ideológico o simbólico, la alfarería de los pueblos prerromanos andaluces no sirve como indicador arqueológico que defina con claridad a los distintos grupos humanos que la usaron. La dispersión de sus formas y de sus decoraciones trasciende las propias fronteras de los grupos protohistóricos meridionales, de manera que pueden encontrarse vasos idénticos al menos por toda la mitad oriental de la Península Ibérica. La transgresión de estos límites geográficos se produce también a nivel interno de las tierras andaluzas, de forma que, así como no es posible desligar al sur de España de la fachada mediterránea, tampoco pueden distinguirse repertorios cerámicos diferenciales entre los distintos grupos que componían la totalidad de los pueblos anterromanos meridionales (Escacena, 1987b. Pereira, 1988a, 1988b y 1989a). Las divergencias se presentan sólo con base en las áreas de distribución de los distintos talleres alfareros, y se comprenden por tanto estudiando los caminos naturales que dieron lugar a redes de comercio o intercambio más que las barreras étnicas. Hablar de vajilla bastetana, turdetana u oretana, por ejemplo, no tendría más valor que señalar repertorios cerámicos aparecidos en territorios controlados -mejor diríamos habitados- por esos pueblos con nombre propio conocido. Pero en ningún caso el contenido de dichos conjuntos mostraría diferencias suficientes como para permitir distinguirlos claramente entre sí, salvo en tipos de piezas muy concretas y con distribución muy restringida. Y, aún en este último caso, existen evidencias de formas de escasa dispersión geográfica que se comercializaron en territorios claramente pertenecientes a etnias distintas (Escacena, 1987b: 175-179).

Mención aparte merece desde luego, por los problemas particulares e interesantes que plantea, la alfarería realizada a mano durante la segunda Edad del Hierro por los Celtici de la Beturia (Del Amo, 1978). Pero este fenómeno puede ser considerado una intrusión minoritaria en la trayectoria general de la evolución que experimentó la cerámica prerromana de Andalucía; tan intrusivo al menos como la propia población que la fabricaba, que desde territorios meseteños se adentró en algunas comarcas de Andalucía occidental para ocupar, sin rivalidades aparentes con los habitantes de la región, un nicho 
ecológico distinto al que explotaban las bases demográficas turdetanas, siguendo a nuestro entender unas directrices parecidas a las que se han descrito para las penetraciones hallstátticas en el País Vasco (Vallespí, 1972: 247).

Una situación similar a la que se deriva del reparto geográfico puede observarse en los aspectos relativos al desarrollo cronológico de esta vajilla de mayor calidad, la pintada de rojo y conocida comunmente como "ibérica": sus límites temporales muestran, tanto en sus momentos iniciales como en su etapa final, evidentes signos de continuidad. Así, el origen de las vasijas pertenencientes a la segunda Edad del Hierro está claramente anclado en los conjuntos cerámicos de época orientalizante que se inspiran en el mundo siropalestino, sólo completados más tarde por diseños de clara raigambre griega a partir de que el helenismo se hace moda en los ámbitos del Mediterráneo central y occidental (Pereira, 1987. Pereira y Sánchez, 1988). Así también, las producciones alfareas pintadas al estilo ibérico no mueren con la conquista romana del territorio, sino que pervivirán hasta época imperial tanto en Andalucía oriental (Arteaga, 1985: 286) como en la depresión inferior del Guadalquivir (Escacena, 1987b). A buen seguro que, de aquí a poco, el conocimiento de esta larga perduración dará al traste con más de un estado ibérico.

Por lo que se refiere a los vasos a torno pintados de rojo con motivos geométricos, su origen debe verse también, como habíamos señalado para la arquitectura de muros rectos, básicamente en la colonización oriental iniciada en el siglo VIII a.C. (Belén, 1978. Belén y Pereira, 1985. Pellicer, 1968 y 1969). Las poblaciones idígenas fueron adquiriendo poco a poco las nuevas técnicas de hornos potentes y oxidantes de los colonizadores, hasta el punto de abandonar por completo, ya en el Hierro Reciente, casi toda huella de lo que fueran las tradiciones autóctonas heredadas de la Edad del Bronce. A raíz de esta adopción surge una dinámica propia que forma una koiné con el mundo ibérico del Sureste y del Levante hispanos al menos. Dicha evolución viene marcada por la adopción de determinados gustos o modas preferenciales en cada momento, pero excepcionalmente puede tener matizaciones específicas en función de demandas sustentadas tal vez en motivos ideológicos más profundos. Sólo barajando causas de esta última índole, tal vez relacionadas con determinadas creencias religiosas y/o con unas filiaciones étnicas específicas, se comprenda la radical desaparición de las comarcas tartésicas de Andalucía occidental, a partir de fines del siglo VI a.C., de los vasos à chardon y de las urnas del tipo "Cruz del Negro", que desde esa fecha sólo se constatarán en la mitad oriental del territorio -especialmente en el Alto Guadalquivir-, donde continuarán su evolución tipológica (Belén y Pereira, 1985).

Además de los aspectos reseñados, la vajilla indígena más lujosa, la pintada de rojo a la que nos venimos refiriendo, conoció influencias y préstamos más locales. A partir del siglo III a.C. ciertos reflejos meseteños, que habían llegado con anterioridad al Alto Guadalquivir (Blanco, 1963: 54. Cuadrado, 1954: 244), penetran hasta las provincias de Córdoba y Sevilla por un lado y hasta las de Granada y Almería por otro, por los mismos caminos terrestres que mucho antes -y en sentido inversose habían ejercido las influencias orientalizantes. Paralelo en el tiempo a esta irradiación de origen septentrional, existió un comercio marítimo expansivo desde el litoral alicantino-murciano hacia Andalucía, fenómeno que debe ser responsabilizado de la llegada de vasijas desde el Sureste hasta las provincias de Málaga y Cádiz al menos, y que durará hasta el cambio de Era si no más (Escacena, 1987a: 298, lám. II).

Hoy puede afirmarse que el carácter industrial de los productos alfareros romanos, con el nacimiento sobre todo de la terra sigillata, pudo ser el factor principal que condujo a la desaparición de los barros pintados locales. Hasta entonces, es decir, hasta los siglos I y II d.C., la cerámica ática primero, la campaniense después, y los vasos de paredes finas en tercer lugar, habían constituido casi con exclusividad los únicos productos cerámicos de lujo adquiridos por las poblaciones indígenas del 
Hierro Reciente y por sus herederas de época romana. Tampoco el consumo de estos bienes de prestigio refleja diferencias sustanciales entre unas etnias y otras, a pesar de las crisis económicas que los territorios ocupados por algunas de ellas pudieron padecer en determinados momentos; porque la marcada ausencia de vasos griegos completos observada en Andalucía occidental en relación con los otros territorios del sur no debe verse a nuestro entender, según se ha sostenido, como "el resultado de la interacción sobre cada sustrato indígena de diferentes grados de «helenización»" (Chapa y Pereira, e.p.), sino que responde claramente a la paralela falta en dicha zona de tumbas pertenecientes a la segunda Edad del Hierro (Escacena y Belén, e.p.). Las sepulturas son, de hecho, los depósitos que han proporcionado la inmensa mayoría de los recipientes áticos enteros en la parte mås oriental de la región; y, si se presta atención a los poblados, donde estas vasijas suelen aparecer fracturadas, las diferencias de comportamiento entre la alta Andalucía y la baja desaparecen por completo.

\section{Las técnicas metalúrgicas}

El carácter reciclable que tienen los objetos de metal, mediante su refundición y posterior conversión en otros nuevos, otorga poca credibilidad a los estudios que pretendan determinar la procedencia de la materia prima empleada en cada caso a través de análisis fisicoquímicos; sobre todo porque cualquier pieza puede ser el producto de la reutilización de varias anteriores fabricadas con materias primas extraidas de lugares muy distintos. Preferimos imaginar, por encima de otras suposiciones, que la advertencia de H. McKerrell y R.F. Tylecote (1972: 218) sobre este peligro, a propósito sobre todo de los útiles de cobre, ha sido quizá la razón que explica la poca preocupación que los arqueólogos han mostrado hasta ahora por poner en manos de los especialistas en metalurgia antigua las pesquisas sobre la procedencia de los materiales empleados para la fabricación de los objetos metálicos de la Protohistoria andaluza. Cabría esperar que la mayor parte de dichos artefactos se hubieran realizado a partir de metales obtenidos en los dos grandes focos mineros de Andalucía: el de Riotinto-Aznalcóllar en las provincias de Huelva y Sevilla, y el de Linares en la de Jaén. No obstante, deben recordarse a este respecto dos cuestiones: la existencia de focos menores y la permeabilidad de las fronteras -antiguas y modernas- a la posible entrada de mercancías desde otras áreas cercanas, en este caso el Sureste español y el mediodía portugués por ejemplo.

Fuera cual fuese el origen de la materia prima, lo que aquí importa es más bien otra cuestión: la de si se observan en el registro arqueológico suficientes diferencias entre las distintas comarcas andaluzas como para usarlas a la hora de delimitar etnias concretas. La respuesta a esta cuestión no es fácil, sobre todo porque puede tener vertientes distintas -y hasta opuestas- según se preste atención a unos u otros aspectos. De hecho, no parece posible observar divergencias fuertes si se atiende al proceso metalúrgico en sí (prospección de zonas metalíferas, extracción en las minas, técnicas de fundición, instrumental usado en cada una de las fases, etc.). Pero cuando el metal adquiere una forma concreta, dando lugar a un artefacto, las cosas empiezan a ser distintas. El hombre deja ya de estar ante un trozo de oro, de cobre o de hierro para encontrarse con una joya para el adorno personal (un brazalete por ejemplo), con una pieza de su propia indumentaria (una fíbula), con un arma con la que ir a la guerra y con la que mostrar su prestigio social (una espada), etc. Y es aquí cuando los distintos productos comienzan a abandonar el carácter de "tecnología metalúrgica" para convertirse a veces en símbolos sujetos a códigos de interpretación cuya lectura obedece con frecuencia a claves religiosas, políticas, étnicas, de jerarquización social, militares, de diferenciación sexual, etc. Es decir, adquieren una carga ideológica y emblemática suficientemente fuerte como para quedar fuera de los aspectos que en este primer bloque estamos analizando. 
En el terreno puramente tecnológico, la metalurgia del cobre, del hierro, de la plata y del oro adquirieron características similares no ya en todos los territorios andaluces, sino también en otros muy apartados de estas tierras. Por lo que al cobre se refiere, las tradiciones locales, heredadas desde la Edad del Bronce al menos, perpetuaron una producción rica en todo el sur durante el Hierro Antiguo. Sin embargo, a partir del Hierro II se observa un auge cada vez más acusado del foco castulonense frente a una decadencia del sector tartésico de Riotinto (González Wagner, 1986b: 136), que había conocido un fuerte declive desde el siglo VI a.C. (Fernández Jurado, 1986: 168, y 1987b: 316). De la muerte del poblado de San Bartolomé de Almonte, que se produjo ya en el siglo VII a.C. (Fernández Jurado y Ruiz Mata, 1985: 32), se deduce que esta crisis de la metalurgia bajoandaluza afectó también a la plata, en cuyo proceso de obtención habían influido mucho las nuevas técnicas introducidas por la colonización oriental. Tanto la arqueología, en unos casos, como las fuentes escritas antiguas, en otros, dan fe de que la caida de la metalurgia tartésica y la escasa explotación del foco minero de Riotinto por parte de las posteriores poblaciones turdetanas, se produjeron de forma paralela a la potenciación del área del Alto Guadalquivir por los oretanos y, más tarde, por los cartagineses (De Frutos, 1991: 112113. Ruiz y otros 1987: 249). Se trata sin duda, por lo que aquí nos importa, de una inclinación de la balanza a favor de Andalucía oriental sustentada en diferencias regionales que en ningún caso estuvieron basadas en particularismos étnicos, sino más bien en factores económicos cuyos orígenes trascienden incluso el ámbito peninsular hispano, para insertarse en las circunstancias internacionales de la política y de la economía de las potencias mediterráneas de cada etapa (fenicios, cartagineses, griegos y romanos sobre todo).

\section{BASES PARA LA DISTINCION}

Para abordar el análisis de lo que de particular y diferenciador presentan los pueblos prerromanos de Andalucía entre sí resulta necesario partir también del Bronce Final; porque conviene recordar que algunos de esos grupos humanos llegarían hasta época romana con unas peculiaridades que sólo a partir del siglo IX a.C. se constatan por primera vez en la región.

En la introducción a este trabajo quedó advertido el lector de que, por debajo de una aparente homogeneidad de las etnias prerromanas andaluzas basada en los estudios tradicionales de la arqueología protohistórica, empiezan a verse en recientes análisis discrepancias de comportamiento sustanciales entre unas y otras (Belén y Escacena, e.p.a.; Bendala y Corzo, e.p.; Iniesta, 1989. Pastor, y otros, e.p. Pereira, 1989b: 478-479. Ruiz, e.p.). Pero estos aspectos diferenciadores afectaron sobre todo a lo que podríamos definir como "campo animológico". Por lo que a éste se refiere, también los estudios se iniciaron en el siglo XIX: L. Siret se preguntó por ejemplo por el origen del rito funerario de la incineración cuando descubrió los más antiguos testimonios sobre el mismo (Siret, 1890: 59-65); G. Bonsor buscó, sobre todo a través de la documentación funeraria, una procedencia extrapeninsular para los colonos de época orientalizante cuyos testimonios creyó encontrar en la comarca sevillana de Los Alcores (Bonsor, 1899).

Dejando a un lado muchas veces, sin duda por su impenetrabilidad, el profundo significado simbólico que contienen muchos de los objetos de la cultura material de dichas comunidades de la Edad del Hierro, bastantes arqueólogos de generaciones posteriores a la de aquellos pioneros han ofrecido para la Andalucía prerromana un panorama uniforme, hasta el punto de que no pocos manuales y tratados generales al uso presentan hoy con relativa frecuencia todo el territorio ocupado por íberos (AlmagroGorbea, 1990: 520-532. Blázquez y otros 1980: 151-170). Esta situación es la responsable de que a 
congresos recientes sobre el mundo ibérico sean convocados también estudiosos de la parte occidental de la región (Simposi Internacional d'Arqueologia Ibèrica. Fortificacions (Manresa, 1990). Congreso Internacional sobre Arqueología Ibérica: Las Necrópolis (Madrid, 1991), un territorio que puede reivindicarse, en atención a muchas de las características del comportamiento cultural de sus pobladores, como área indoeuropea más que como ibérica (Escacena, 1989). Distinto habría sido el panorama si los arqueólogos hubiesen buscado la filiación étnica de los Turdetanos con un bloque u otro basándose en la lengua; porque los filólogos tienen claro al menos que el habla de las gentes que habitaron el Bajo Guadalquivir durante el Hierro Reciente no es la misma que la de los íberos (Correa, 1989: 281. Tovar, 1987: 37-41. Untermann, 1984: fig. 11. Villar 1991: 438), sea cual fuere la filiación de esta última.

Sin duda, adelantar ahora cosas que se tratarán con más profundidad en las líneas que siguen, tiene más la intención de provocar la reflexión metodológica y teórica sobre el análisis de las etnias prerromanas, que ofrecer datos más o menos interesantes sobre cada una de ellas. Y esta reflexión exige por lo menos exponer una serie de consideraciones sobre determinados aspectos concernientes a estos pueblos por los que la arqueología se ha preguntado hasta ahora bastante poco. Conste de nuevo que se trata de cuestiones más de índole espiritual que material, aunque el acceso a muchas de ellas se deba llevar a cabo, por agotamiento de las fuentes literarias, a través de documentos, técnicas y métodos arqueológicos. Pueden presentarse aquí mediante el contraste de una realidad dual: la que pone de manifiesto las diferencias profundas entre dos Andalucías (la alta y la baja, la oriental y la occidental, la del Mediterráneo y la del Atlántico) que todavía hoy son relativamente distintas en el folclor, en el carácter de sus gentes y hasta en algunos aspectos lingüísticos.

\section{Los dioses y el culto}

En lo que se refiere a las divinidades veneradas por los pueblos protohistóricos de Andalucía, la documentación del Bronce Final revela una situación a primera vista igualitaria para todo el territorio. El verdadero carácter homogéneo del horizonte precolonial estriba fundamentalmente en la ausencia de representaciones divinas de cualquier tipo. Estas condiciones pueden reflejar un panorama engañoso, porque la posible existencia de dioses anicónicos no demuestra necesariamente que en todas partes esa falta de imágenes respondiera a una igualdad de creencias, como tampoco hoy obedece a la existencia de una misma religón la tendencia a no representar a la divinidad en el Islam y en la Europa luterana por ejemplo. De hecho, parece que el hiato poblacional que precede al Bronce Final en el Bajo Guadalquivir (Belén y Escacena, e.p.a) desvincula al panteón que se adorara en esta zona de cualquier posible precedente en el Bronce Medio local, aunque en éste tampoco se conozcan representaciones materiales de los dioses y haya que remontarse al Calcolítico para encontrarlas. En muchos puntos de Andalucía Oriental en cambio, si se sostuviera la existencia de una fuerte continuidad entre las fases media y/o tardía del Bronce y la final, habría que mantener que las poblaciones indígenas anteriores al Hierro Antiguo serían herederas asimismo de la carga religiosa de los grupos que las precedieron, con lo que el panteón argárigo, o al menos el postargárico del Bronce Tardío, tampoco conocido en representaciones plásticas salvo en muy raras excepciones que se interpretan casi siempre como manifestaciones tardías del mundo eneolítico (Almagro Corbea 1973: 31-32), sería básicamente el mismo al que a la larga darían culto los grupos del Bronce Final. Esta última explicación referida a la alta Andalucía es sin duda problemática -y no desde luego la única posible-, pero es la consecuencia lógica que deberían admitir al menos quienes defiendan para aquella región la inexistencia de discontinuidad entre el Bronce Final y las fases precedentes de la misma Edad del Bronce. 
Fuera o no ésta la situación que antecedió a la etapa protohistórica, la documentación arqueológica reflejará a partir de época orientalizante una incipiente dicotomía entre las mitades oriental y occidental de la región. Las imágenes de dioses conocidas a partir de esta fecha y durante todo el primer Hierro reflejan tan fuerte impacto oriental que parecen más el panteón de colonos que el de indígenas aculturados. La Astarté del Carambolo (Lipinski, 1984: 102-117), la Dama de Galera (RIIS 1950), o las dos figurillas de Melkart halladas en Huelva (Gamer-Wallert, 1982) son tan orientales, en su forma y en lo que representan, como el lote de divinidades en bronce rescatadas hace pocos años en Cádiz (Blanco, 1985), por lo que carece de toda lógica vincular el primer conjunto a cultos practicados por grupos humanos autóctonos y el segundo a una religión de extranjeros, como normalmente se hace. La distinción entonces entre las dos Andalucías parece responder durante el Hierro Antiguo más a cuestiones de número que de contenido, con una diáfana inclinación de la balanza hacia el oeste si se incluyen en esta documentación los marfiles tartésicos que aluden a temas religiosos (Aubet, 1979, 1980 y 1981 82). No obstante, a la llegada de la segunda Edad del Hierro quedó bruscamente rota esta tendencia, pues a partir de finales del siglo VI y de comienzos del V a.C. el Bajo Guadalquivir y sus áreas periféricas, esto es, lo que vendría a constituirse en tiempos prerromanos como el área turdetana, conocería de nuevo una ausencia total de representaciones divinas, mientras los territorios de Andalucía Oriental y del Alto Guadalquivir, ocupados sobre todo por los grupos bastetano y oretano, experimentarían una fecunda producción de imágenes, unas veces de dioses y, las más, de exvotos y de gestos rituales relacionados con el culto que se les rendía (Chapa, 1990. González, 1990. Marín y Belén 1986-87. Negueruela, 1990. Nicolini, 1977. Presedo, 1973. Etc.). En toda esta parte este de la región, especialmente en el sector jiennense de Sierra Morena, son relativamente abundantes los santuarios en lugares altos. Las necrópolis de esta mitad oriental albergaron tal cantidad de representaciones divinas y de animales mitológicos que debieron constituir verdaderos puntos de encuentro religioso para el culto comunal tanto como ciudades de los muertos. En cambio, en la Turdetania falta por completo toda una gama de seres mitológicos propios del mundo ibérico, como las esfinges, los grifos, las sirenas, los caballos alados y los toros androcéfalos (Chapa, 1985).

Parece evidente, a la altura en que hoy se encuentra la investigación, que la escasez de escultura sagrada durante el Hierro II en Andalucía occidental no responde ni a la falta de conocimiento arqueológico de sus comarcas ni a caprichos del azar, razones esgrimidas por los que esperan pacientemente que algún día los Turdetanos se muestren en este campo tan fecundos como las etnias oretana y bastetana. Por lo que sabemos, ni en la provincia de Huelva, ni en la de Sevilla, ni en la de Cádiz, ni en la de Málaga, ni en gran parte de la de Córdoba, han aparecido esculturas en piedra de dioses antropomorfos, como en cambio ocurre en Andalucía oriental y en el Sureste; y, si bien Cádiz capital resulta una excepción en este panorama a causa del hallazgo de una dama sedente del tipo de la de Baza (Marín y Corzo, 1991), no parece difícil dar una explicación de este dato aludiendo al carácter cosmopolita de dicha ciudad en la Antiguiedad -y durante casi toda su historia-, que debió quedar reflejado también en los ritos funerarios atestiguados en su necrópolis según se ha apuntado recientemente (Belén, e.p.), o al texto de Estrabón (III,2,1) según el cual los Bastetanos habitaban una estrecha franja costera desde Kalpe a Gades. Y, por lo que se refiere a representaciones animalísticas, sobre todo de leones supuestamente asociados al mundo funerario, las de Andalucía occidental son verdaderamente escasas, y constituyen hallazgos cada vez menos numerosos y cronológicamente más recientes coforme se penetra hacia la parte de poniente del territorio, hasta el punto de que faltan en gran parte de las provincias de Sevilla y Cádiz y están completamente ausentes de la de Huelva (Chapa, 1985: 137. Escacena, 1989: 464). 
Las diferencias, pues, entre las dos mitades de Andalucía se hacen patentes sobre todo en la vinculación del sector oriental (etnias bastetana y oretana especialmente) al mundo religioso ibérico del sureste meseteño y de la fachada mediterránea española, fecundo a la hora de dar representación material a sus dioses, a otros entes mitológicos menores y a determinados gestos cultuales (exvotos oferentes entre otras cosas), y del occidental (comunidad turdetana) al indoeuropeo atlántico no celta, que, por no tenerlo aquí por ateo ya que andando el tiempo llegaría a adoptar de buen grado a los dioses romanos, tal vez sea mejor imaginarlo con un panteón anicónico desde el Bronce Final.

En consecuencia, el origen de esta dualidad no parece residir en asuntos superficiales y que tengan que ver sólo con la forma de representación, material o no, de las divinidades, sino en convicciones más profundas, que afectaron sin duda a la propia identidad de lo divino, a los nombres con que los dioses eran invocados y a las maneras como los distintos grupos humanos les dieron culto. En este sentido, la religión acaba por convirtirse en uno de los marcadores culturales que mejor individualizan a las distintas etnias entre sí o, al menos, a grupos de ellas. Además, en el caso concreto que nos ocupa, sugiere orígenes en raíces ancestrales radicalmente distintas: para los Turdetanos podría encontrarse una fuerte vinculación con el sustrato precolonial de finales de la Edad del Bronce; pero para los Bastetanos y Oretanos la interpretación posible discurre por caminos más complejos y tortuosos sobre los cuales pueden hacerse todavía unas cuantas reflexiones.

La hipótesis de una continuidad poblacional entre el Bronce Medio-Tardío y el Final en el sector oriental de Andalucía permitiría, según antes quedó indicado, aceptar que el panteón y las formas de relación del hombre con los dioses serían allí en época protohistórica en gran parte la herencia de situaciones anteriores al Bronce Final. Pero existen datos que sugieren que este esquema no puede hacerse extensivo a todo el territorio. De hecho, la afirmación del periplo marsellés recogido por Avieno (Ora Mar. 466) de que los íberos comenzaban más allá del Alebus amnis, es decir, del río Vinalopó (Tovar. 1985-86: 17), y la circunstancia de que se haya constatado en determinadas comarcas un horizonte del Bronce Final muy parecido al del Bajo Guadalquivir (Abad, 1979: 186-187), hablan de la posible ocupación de dichas zonas por las mismas poblaciones que originaron el complejo cultural de la fase tartésica precolonial de Andalucía occidental. Estos datos aconsejan admitir que las tierras sobre las que se asentaron los grupos que a la larga serían conocidos con el nombre de Turdetanos rebasaron a finales de la Edad del Bronce los límites geográficos del oeste andaluz, para extenderse mucho más allá en dirección a levante. Tal vez en esta circunstancia se apoye el dato, transmitido también por Avieno (Ora Mar. 449-464), según el cual Mastia perteneció un día a los tartesios (González Warner 1986a: 223).

El panorama descrito revela una enorme complejidad interpretativa, y choca desde luego con gran parte de las ideas mayoritariamente aceptadas hoy por los investigadores acerca del proceso de formación del mundo ibérico; sobre todo porque, desde este punto de vista, la ocupación inmediatamente anterior al Hierro Antiguo -y tal vez también durante éste- en muchos puntos de esas áreas orientales de Andalucía se debería a una población indoeuropea, que no pudo ser por tanto la causa directa del nacimiento de los íberos posteriores. En consecuencia, estos últimos debieron constituir el legado de los antiguos grupos locales del Bronce Medio-Tardío, en convivencia durante el Bronce Final con esos otros de vinculación atlántica y bajoandaluza, o bien -¿quizás también?- el producto de la expansión de las comunidades del Sureste hacia el Alto Guadalquivir y hacia las tierras montañosas de Andalucía oriental, comunidades que desde finales del siglo VI a.C. o comienzos del V conocían una más que próspera situación. Así, la iberización del territorio podría interpretarse, al menos parcialmente, más como un movimiento demográfico y cultural expansivo desde el Sureste hacia la alta Andalucía que como la herencia directa de lo tartésico, sin que esta interpretación niegue a su vez que el origen del 
auge que conoció el Sureste deba verse en una previa eclosión, e irradiación hacia la periferia, del mundo orientalizante de la baja Andalucía durante el siglo VII a.C. principalmente.

Las implicaciones lógicas de toda esta compleja hipótesis, por lo que se refiere al plano religioso, es al menos admitir que los dioses adorados por los íberos oretanos y bastetanos, las etnias protohistóricas más relevantes de Andalucía oriental si se mantiene al margen el problemático mundo de la costa mediterránea, tuvieron nada o muy poco que ver en su génesis con el panteón de los Turdetanos y con el de otros indoeuropeos (Celtici) de la parte oeste de la región. Por tanto, en las diferencias sustanciales de estos dos complejos animológicos, de los códigos simbólicos a los que hacían referencia y de los ritos que en torno a ellos se desarrollaron, podría encontrar cobijo una explicación de la profunda y radical dicotomía que la arqueología de la religión observa cuando estudia una y otra partes del territorio andaluz.

\section{El mundo de la muerte}

De unos años a esta parte, el conocimiento cada vez más profundo de la cronología de la cerámica a torno pintada de Andalucía conocida comunmente como "ibérica" (Escacena, 1987b. Pereira, 1988a, 1988b Y 1989a), así como de sus precedentes (Belén, 1978. Belén y Pereira, 1985. Pellicer, 1968 y 1969. Ruiz Mata, 1987) ha permitido fechar con relativa precisión muchas tumbas portadoras de ese tipo de tiestos, y descubrir en consecuencia un comportamiento diferencial entre las comarcas orientales y occidentales de Andalucía por lo que se refiere a las creencias en el más allá o, por lo menos, a las costumbres con que los vivos despedían a sus difuntos (Belén y Escacena, e.p.b. Escacena y Belén, e.p. Pereira, 1989b: 478-479). A finales del siglo XIX, las excavaciones de Bonsor en la región de Carmona habían puesto al descubierto dos o tres incineraciones contenidas en vasijas de esta clase (Bonsor, 1899: 125-126). Desde aquellos años hasta hoy muy pocos testimonios nuevos se han añadido al repertorio de sepulturas conocidas, de manera que toda una centuria de investigaciones ha conseguido para cinco siglos de vida de los Turdetanos no más de diez o doce enterramientos. Si a esta circunstancia se une el hecho de que gran parte de ellos corresponden a tiempos romanos, como ocurre por ejemplo con un conjunto hace poco excavado en Ecija (Núñez y Muñoz, 1988: 431), el registro arqueológico de la segunda Edad del Hierro aparece en la baja Andalucía al menos como una fase de fuerte contraste con la etapa orientalizante que la precedió (Escacena, 1989: 465-467), pues de esos momentos tartésicos sí se conoce documentación funeraria en relativa abundancia (Aubet, 1982. Ruiz Delgado, 1989. Ruiz Mata, y Pérez, 1989). Así, la revisión de la cronología de las tumbas tenidas por turdetanas y el recuento completo de las mismas suministran una base más que suficiente para afirmar que existieron entre ambas mitades del territorio andaluz diferencias tan radicales que provocaron el nacimiento de auténticas necrópolis sólo en el lado oriental.

En efecto, si se echa mano de los testimonios arqueológicos se observa que las incineraciones funerarias y los auténticos cementerios que las acogen abundan a partir del siglo V a.C. exclusivamente en las provincias del este, mientras faltan por completo o son verdaderamente excepcionales en las de poniente, hasta tal punto que la presencia/ausencia de necrópolis, arqueológicamente entendidas al estilo tradicional, podría usarse como indicador étnico que permitiera establecer los límites que en cada momento separaron a los Turdetanos de otros grupos situados en áreas más orientales.

Que los Turdetanos careciesen de cualquier tipo de necrópolis choca sobremanera con toda deducción hecha a partir de datos etnográficos, pues, salvo en contadas ocasiones en que algunos grupos sociales dentro de una etnia -pero no la etnia entera- no reciben tratamiento funerario alguno y son prácticamente abandonados por su propia comunidad, desde que el hombre moderno -el sapiens 
sapiens - sustituyó a otros anteriores, todas las culturas han desarrollado algún sistema de ritos para despedir a sus mayores del mundo de los vivos (Chapa, 1991: 14), lo que normalmente ha incluido la elección de un lugar sagrado para albergarlos. De ahí que, aparte del cuerpo de dogmas que diera soporte a las creencias en el más allá, la diferencia fundamental con los Bastetanos y Oretanos estribe en los gestos cultuales en torno a la muerte y en los lugares consagrados como sitio de reposo último de los difuntos, cosas que en parte se desconocen casi por completo porque muchas veces ni siquera dejaron huellas materiales.

Con base en estas últimas se sabe al menos que los íberos de Andalucía oriental, como los del Sureste y los de Levante, y como otros muchos pueblos contemporáneos de la cuenca mediterránea, quemaron a sus muertos en piras funerarias y luego enterraron sus cenizas en necrópolis localizadas fuera de los lugares de habitación. Estas se disponían en uno o varios núcleos en torno al poblado, como de hecho ocurre en Castulo (Blázquez, 1975 y 1979. Blázquez, y Fernández Uriel, 1974. Blázquez y Molina 1973. Blázquez y Remesal, 1975) y en Baza (Presdeo, 1982: 12) por ejemplo. Se ha propuesto que algunos de estos cementerios habrían conocido una estructura interna bien planificada, en la que las tumbas de los distintos personajes importantes habrían ocupado lugares más destacados en el conjunto y habrían servido como elementos aglutinantes de otras sepulturas pertenecientes a individuos de menor rango (Ruiz y Hornos, e.p.). Las implicaciones de esta hipótesis obligarían a admitir que cada persona tenía prefijado el día de su muerte en función del grupo social al que perteneciera y del lugar que tendría que ocupar en el sector del cementerio que la comunidad le tenía reservado para el descanso eterno, o bien que existió un urbanista que al diseñar la necrópolis supo captar el futuro, con la clarividencia de un clarividente, a cuatro o cinco siglos vista; cosas que chocan frontalmente con una mínima dosis de sentido común.

Al igual que hacían las poblaciones ibéricas no andaluzas, también los Bastetanos y Oretanos colocaron como ajuar en los enterramientos las armas de los guerreros, algunos objetos del atuendo personal, joyas y hasta piezas destinadas a usos lúdicos, cuando no elementos que, como las fusayolas por ejemplo, parecen aludir en muchos casos a funciones domésticas desempeñadas al parecer por mujeres. Las tumbas más ricas contuvieron además ofrendas de comida y bebida, vasijas que habían servido para libaciones durante los ritos fúnebres, frascos con perfumes y ungüentos caros, recipientes de cerámica griega, etc. (Pereira, 1989b: 485-488).

Todo este panorama resulta, por el contrario, extraño a Andalucía occidental; porque los Turdetanos no parece que dieran sepultura a sus muertos según estas costumbres antes descritas. En realidad, desde el Bronce Final (Belén, y otros, e.p.) hasta prácticamente el cambio de Era no se conocen en el Bajo Guadalquivir y sus territorios periféricos más enterramientos que los de época orientalizante casi con exclusividad, circunstancia que sugiere que tales testimonios deben suponer un verdadero paréntesis en la trayectoria histórica de la región. Con base en el carácter excepcional de estos últimos y en los símbolos religiosos encontrados en algunos de ellos (mitología recogida en las escenas representadas en los marfiles) se podría proponer que las sepulturas tartésicas hasta hoy conocidas perternecieron en su origen a comunidades extranjeras asentadas en el país de los Turdetanos, que colonizarían la región con intenciones básicamente agropecuarias (González Wagner y Alvar, 1989), ya que ni el enterramiento en urna cineraria ni las estructuras tumulares por ejemplo, dos de las características más singulares de estas costumbres funerarias, tenían precedente alguno en el horizonte autóctono precolonial. La población indígena en cambio, la que llegaría con el tiempo a prestar su propio nombre étnico al territorio según testimonio de Estrabón (III,1,6), hizo con sus antepasados muertos algo que todavía nos es documentalmente desconocido, pero parece al menos que no los alojó desde luego en recipientes cinerarios agrupados en necrópolis como hoy la arqueología tradicional las entiende. 
La ausencia de registro funerario evidente en Andalucía occidental desde fines de la Edad del Bronce coincide con un fenómeno semejante que caracteriza en realidad a gran parte de la fachada atlántica del continente europeo y de las Islas Británicas. M. Ruiz-Gálvez ha señalado en varias ocasiones cómo, en efecto, desde las costas alemanas hasta Gibraltar como límites más estrechos, la carencia de enterramientos marca arqueológicamente a las comunidades del Bronce Atlántico (RuizGálvez, 1984: 252, y 1991: 282). Este comportamiento es más antiguo conforme más al norte y, por otra parte, discurre de forma paralela a la progresión también hacia el sur del rito de arrojar armas a las aguas (Ruiz-Gálvez, 1982), que tiene su exponente más meridional fuera incluso del continente europeo, en concreto en la Ría de Larache (antiguo río Lucus), en el Marruecos atlántico (Ruiz-Gálvez, 1983). Si, por otra parte, se hace un recuento de los lugares de procedencia de las armas prehistóricas aparecidas en contextos controlados, se observará, como de hecho ocurre en toda la Cultura Argárica por ejemplo, que un altísimo porcentaje de ellas procede de conjuntos funerarios. De ahí que la circunstancia de que la desaparición de enterramientos se produzca de forma paralela al surgimiento del fenómeno de los depósitos de armamento en medios acuáticos, sugiera que eran los ríos y los lagos los lugares donde también se arrojaba a los cadáveres, quemados o no previamente. Como se ha propuesto de hecho para algunas regiones inglesas (Darvill, 1987: 118-120), esta hipótesis podría explicar para la fachada atlántica hispana la total ausencia de tumbas atribuibles al Bronce Final (Belén, y otros, e.p.), con lo que los hallazgos de armas en las aguas quedarían reivindicados como ajuares funerarios y, en atención a la propuesta de Bradley (1990: 102-103), también como un auténtico potlatch. Por poner un claro ejemplo andaluz, la Ría del Odiel constituiría la necrópolis indígena de la Huelva tartésica (Albelda, 1923. Almagro, 1940 Y 1975. Terrero, 1991).

Existen paralelos etnográficos, tanto en la Antigüedad como hoy en día, que apoyan esta interpretación (recuérdese el caso actual de la India por ejemplo). Pero el problema fundamental que este comportamiento en torno a la muerte plantea es la casi total imposibilidad de comprobarlo en la práctica mediante técnicas de excavación arqueológica. No obstante, existen cada vez más datos en favor de esta hipótesis (Bradley e Gordón, 1988), lo que proporciona un importante apoyo material a una de las vías mitológicas indoeuropeas de acceso al más allá: el "camino de las aguas". Por lo que se refiere a los Turdetanos de la segunda mitad del primer milenio a.C., puede sostenerse, en consecuencia, que, si las tumbas de época orientalizante constituyen un verdadero paréntesis en la evolución del mundo funerario de la protohistoria bajoandaluza por manifestarse entre dos grandes vacíos, el del Bronce Final y el del Hierro II, las poblaciones de este segundo momento darían tal vez sepultura a sus difuntos como lo hicieron las del primero, perpetuando así una tradición indoeuropea precelta vinculada a las comunidades del Bronce Atlántico (Escacena, 1989: 467). Esta sería la razón fundamental que explicaría la ausencia de enterramientos turdetanos y de necrópolis para acogerlos en la forma en que a los unos y a las otras los entendían los íberos.

Es cierto que los escritores grecolatinos no aludieron a tales costumbres. Pero ¿acaso las fuentes literarias antiguas nos contaron todo acerca de los pueblos de la Península Ibérica?; y, de haber sido así, ¿qué papel tendría que desempeñar entonces la arqueología?.

Tocante al mundo de la muerte, puede afirmarse pues, en síntesis, la existencia de una profunda dicotomía entre la Andalucía ibérica de Oretanos y Bastetanos y la indoeuropea de los Turdetanos. Estas fuertes diferencias debieron tener indudablemente sus raíces en concepciones religiosas del mundo también diversas, y desde luego se plasmaron materialmente en unos comportamientos rituales que han dejado un registro arqueológico muy distinto entre el oriente y el occidente del territorio meridional hispano. 


\section{La lengua}

En coincidencia con los filólogos, de un tiempo a esta parte parece que, ciertos arqueólogos al menos, empiezan e tener relativamente claro que es el idioma el mejor baremo para clasificar a los pueblos, de manera que, por poner un ejemplo, sólo serían celtas aquellas gentes que, sobre todo, hablaron una lengua celta. Por otra parte, a propósito de ciertas hipótesis sobre el origen oriental de las lenguas indoeuropeas, se ha insistido recientemente, recogiendo la propuesta de T. Dragadze (1980), en la definición de "etnia" y en la necesidad de no identificarla necesariamente con lengua, con raza y con cultura material (Renfrew, 1990: 176-178). En este sentido, es cierto que la tecnología descargada de contenido simbólico puede trascender las fronteras del habla, y que una misma lengua puede ser usada por varios grupos étnicos.

No obstante, tales cuestiones no están del todo claras al parecer para muchos de los historiadores y arqueólogos que han abordado el análisis del mundo ibérico. De hecho, a pesar de que los filólogos han demostrado que los Turdetanos no pertenecieron al mismo tronco lingǘ́stico que los íberos (Correa, 1989: 281. De Hoz, 1989: 561-565. Tovar, 1987: 37-41. Untermann, 1984: fig. 11.), la tradición historiográfica reciente ha llevado a no pocos investigadores a estudiar a aquéllos en el conjunto de éstos (Bendala, 1979. Carriazo, 1980. Escacena, 1987a. López Palomo, 1980. Pellicer, 1976-78 y 1979-80. Pereira, 1989b). La razón última que ha marcado tradicionalmente la inclinación hacia esta opción quizás resida en la creencia de que el mundo turdetano fue heredero directo del tartésico orientalizante, cosa que, como se ha visto en las ideas que anteceden, no parece sostenerse más que en cuestiones de tecnología que no tuvieran que ver con el plano animológico.

Refiere Estrabón $(I I I, 1,6)$, al hablar de la Turdetania, que sus habitantes eran de escritura y de lengua distinta a la de los íberos, lo que corroboran los estudios filológicos actuales (De Hoz, 1989. Untermann, 1984: fig. 11, y 1985: 9.). Su etnónimo estaba emparentado sin duda con el de los Túrdulos y con el de los denominados por las fuentes Turduli veteres, por no citar otros pueblos aún más septentrionales, apelativos que portan el mismo radical. De ahí que Estrabón $(I I I, 1,6)$ llegara a afirmar que, aunque en tiempos de Polibio se observaban diferencias entre los Túrdulos y los Turdetanos, en su época no era posible distinguirlos. En consecuencia, los arqueólogos que defiendan el carácter ibérico de estos últimos deberían ser consecuentes con dichas cuestiones y aplicar la misma filiación a las otras etnias citadas, lo que normalmente no se hace por no llevar el mundo ibérico hasta Extremadura o hasta tierras del Duero, cosa en extremo chocante con la información que se posee de esas áreas meseteñas.

Las presentes reflexiones no son evidentemente las de un especialista en cuestiones lingüísticas, por lo que en estos terrenos se limitan a aspectos interpretativos, sin entrar en pormenores. Con esta aclaración no se pretende tanto justificar la brevedad de tales comentarios y sus posibles errores como provocar en el lector la misma preocupación sobre el divorcio entre lingüistas y arqueólogos que ya mostrara Caro Baroja en su conocida obra sobre las poblaciones de la España antigua (Caro Baroja, 1976: 69).

Los estudios sobre onomástica, toponimia, hidronimia y oronimia revelan que en los territorios ocupados por los Oretanos y Bastetanos se habló durante el Hierro Reciente un dialecto ibérico, entroncado con la lengua del Sureste y Levante o tal vez el mismo (Tovar, 1987: 37. Untermann, 1984: fig. 11). En momentos anteriores la situación pudo ser distinta, porque la transformación fonética del topónimo ip-l-ip(p)o, por ejemplo, en obu- (caso de Ipolka > Obulco) (De Hoz, 1989: 554-557), basada en la inexistencia de la labial sorda en el ibérico (De Hoz, 1989: 529. Villar, 1991: 432), demuestra que existió un horizonte fundacional de poblados, previo al establecimiento o a la generalización de la 
lengua de los íberos, que Tovar (1985-86: 20) quiso reconocerlo como celta, pero que hoy parece que debe ser vinculado mejor al mundo turdetano o, lo que es lo mismo, al complejo lingüístico que los filólogos denominan "meridional" o "andaluz". Recuérdese, a este respecto, que durante el Bronce Final se observaba esta dependencia cultural de muchos puntos de Andalucía oriental y del Sureste con respecto al mundo bajoandaluz preorientalizante (Abad, 1979: 186-187), y que las fuentes literarias (Avieno, Ora Mar. 449-463) hacen referencia a la extensión de Tartessos hasta tierras murcianas y alicantinas (González Wagner, 1986a: 223).

Untermann ha defendido un movimiento demográfico en el sector meridional de la Península Ibérica en sentido este-oeste (1985: 14-15). Producto de este fenómeno fue sin duda la sustitución o la superposición de poblaciones en determinadas zonas de Andalucía oriental y del Alto Guadalquivir, de manera que tal vez grupos de habla indoeuropea asentados allí a finales de la Edad del Bronce o comienzos de la del Hierro fueron desplazados o absorbidos por poblaciones ibéricas. Este dinamismo se plasmó en la estratificación de capas lingüísticas, y tiene en la progresión hacia occidente del topónimo ibérico ili- (Villar, 1991: 440) quizás el más evidente de sus puntos de apoyo, si bien este elemento ha sido considerado también préstamo entre gentes de hablas distintas en contacto o "lexema viajero" de difícil atribución a una familia concreta (De Hoz, 1989: 562-563). El desplazamiento de poblaciones que dio lugar a esta expansión meridional de la lengua ibérica ha sido fechado a partir del siglo IV a.C. (Untermann, 1985: 15-16); pero la arqueología sugiere, por ejemplo en los casos concretos de la cerámica (Escacena, 1987b: 1085) y de la escultura en piedra (Chapa, 1985: 137 ss. Escacena, 1989: 463-465), que no llegó hasta el Bajo Guadalquivir más que a partir de fines del siglo III a.C., en coincidencia con un fenómeno similar observado en algunas tierras del valle medio-alto del río (Montilla y otros 1989: 147), y sobre todo en momentos contemporáneos a la dominación romana, sin que sepamos en este caso si fomentado o no por los nuevos dueños del territorio.

Los etnónimos de los pueblos prerromanos de Andalucía nos han llegado sólo a través de las fuentes escritas grecolatinas. En este hecho se basa en parte nuestro desconocimiento sobre su significado. Acerca del Bajo Guadalquivir, se sabe que fueron sus habitantes los que acabarían por imponer su propio nombre a la región que ocuparon, denominándose Turdetania por tal motivo y Bética en alusión al río principal que la recorría según cuenta Estrabón $(I I I, 1,6)$. Pero no concurren las mismas circunstancias en los casos bastetano y oretano. Como los Turdetanos se denominaron con dicho apelativo no en función del área que ocuparían durante la segunda Edad del Hierro, sino al parecer por otros motivos (Escacena, 1989: 439), no existió nunca una capital de nombre Turdetum que diera origen al etnónimo, a pesar de que ese hipotético núcleo principal ha sido a veces afanosamente buscado desde tiempos de Rodrigo Caro (1634: 136). Para los Oretanos y Bastetanos conocemos en cambio dos ciudades, de nombre Oretum (Nieto y otros 1980: 12-17) y Basti (Alvarez, 1952: 274), que llevaron respectivamente el mismo radical que cada una de esas etnias; de ahí que en este caso pueda pensarse en una denominación del grupo humano basada más en cuestiones de ubicación geográfica que en otros aspectos. Pero nada hay todavía seguro sobre estas cuestiones.

En resumen, se puede afirmar que los comportamientos culturalmente diferenciadores entre Andalucía occidental y oriental tienen también como base una dualidad linguística de raíces ancestrales y profundamente distintas. Si la continuidad poblacional del Bajo Guadalquivir, vista de forma retrospectiva a partir de tiempos romanos, conoció una fuerte ruptura previa al Bronce Final, manifestada en un vacío demográfico centrado entre los siglos XII y X a.C. sobre todo, hay que concluir que fue en época tartésica precolonial, esto es, en el siglo IX a.C., cuando se instaló en el territorio ese sustrato lingüístico, que, como el Lusitano (Gorrochategui, 1985-86: 88. Tovar, 1985-86: 22-23. Villar, 1991: 459. En contra Untermann, 1985-86: 67-69), debería ser indoeuropeo precelta en atención a la vinculación que 
en muchos aspectos de su cultura muestra el grupo humano que lo habló con las comunidades del Bronce Atlántico. Frente a esto, los lazos de los Bastetanos y Oretanos con los demás íberos instalan el problema de la raíz de su lengua, tal vez común para ambos grupos, en el mismo plano en que hoy se sitúa la problemática del origen del ibérico, dividido entre quienes lo creen la evolución de hablas paleolíticas de la fachada mediterránea española, sin vínculos con ningun idioma actual conocido, y quienes sostienen, tras un previo enlace con el vasco, un entronque con lenguas afrosaharianas de la familia camita (cf. Arribas, 1976: 32-33. Caro Baroja, 1976: 65-67. Villar, 1991: 438), que entrarían en la Península Ibérica, con la Cultura de Almería y/o complejos afines (Bosch, 1974a: 4-6, 1974b y 1974c: 329-330. Schulten, 1920: 109), tal vez en los últimos siglos del IV milenio a.C. aproximadamente.

\section{CONCLUSION Y SINTESIS}

Es evidente que las ideas expuestas en las líneas que anteceden son la consecuencia de una manera concreta de entender el registro arqueológico. $\mathrm{Si}$, como se ha dicho hasta la saciedad, las evidencias materiales de las culturas antiguas son mudas, hacerlas hablar exige optar por un método de los muchos posibles. En este sentido, unos arqueólogos han preferido caminos que a la larga les llevarían a conclusiones enfrentadas con la información que suministran las fuentes escritas antiguas. De ahí se ha derivado cierto descrédito para los tratadistas grecolatinos a la hora de usarlos como fuentes históricas (Chapa y Pereira, e.p.), como de hecho se ha sostenido para Estrabón por ejemplo (Arce, 1989). Pero otros investigadores, partiendo de un buen grado de escepticismo sobre la posibilidad de que los datos arqueológicos contengan en sí mismos deducciones históricas, han optado por buscar veredas que, aunque parezcan más dificultosas, puedan compaginar no sólo todo tipo de información que nos haya llegado sobre el mundo antiguo (literaria o arqueológica), sino ese bloque en su conjunto con estudios etnográficos relativos a poblaciones primitivas actuales, con análisis de antropología física, con inferencias realizadas a partir de la filología, con la historia de las corrientes artísticas, etc. En este segundo bloque debe situarse el presente artículo, que sólo ha pretendido buscar cuáles sean algunos de los marcadores culturales que sirven para diferenciar las distintas etnias de la Andalucía prerromana.

Mucho queda todavía por investigar en esta parcela, porque la realidad histórica fue sin duda bastante más compleja que el sencillo panorama aquí presentado. De hecho, si nos atenemos a los estudios de los filólogos, tendríamos que concluir con ellos, como bien ha propuesto J. de Hoz (1991: 40) al divulgar cuestiones relativas a las lenguas celtas hispanas, que la Península Ibérica toda constituyó durante la Edad del Hierro un mosaico de lenguas extraordinariamente complejo, repleto de grupúsculos de gentes más móviles de lo que en principio podría imaginarse. Esta circunstancia no permite dividir sin más el territorio en las dos grandes áreas lingüísticas (ibérica e indoeuropea) que a grandes rasgos puede observarse, y aconseja reconstruir la realidad del primer milenio a.C. con base en un complejo rompecabezas de pueblos y de lenguas en constante dinamismo (Villar, 1991: 427). La arqueología tiene por delante una senda dificultosa, pero prometedora, si se adentra por estos caminos interpretativos, y no faltan ya sugerentes ejemplos de esta línea de trabajo en la que la lengua y la información textual clásica acaban compaginándose con la documentación arqueológica (Luzón, 1990); pero, siguiendo los consejos de F. Villar (1991: 55), debe relegar al olvido esquematismos tan reduccionistas como los que se han propuesto para explicar la llegada de las lenguas indoeuropeas a la Península Ibérica a partir del Neolítico (Renfrew, 1990: 134 y 188).

La vinculación lingüística de una generación con la que le precedió es normalmente muy elevada, y conlleva la aceptación de unas pautas culturales a la vez que el rechazo de otras. Si la lengua supone 
quizás la principal cadena de transmisión por la que los individuos quedan enculturados en un mundo concreto (Villar, 1991: 8), los arqueólogos deberían intentar saber, por lo menos cuando estudian las etapas históricas que dispusieron de escritura, a qué tronco lingüístico pertenecieron los autores de las culturas que analizan, y, en función de él, abordar el desciframiento de las huellas materiales que su quehacer diario produjo.

Por coherencia con lo antedicho, la conclusión fundamental que habría que anotar en estos párrafos finales es sin duda más de carácter metodológico que de otro tipo. En este sentido, no es necesario reiterar argumentos que han sido expuestos al principio; pero sí oportuno traer a colación nuestra coincidencia teórica con la "primera reflexión" de F. Nocete (1989: 38) a propósito del estudio de la sociedad del Cobre final y de la transición al Bronce en las campiñas del Alto Guadalquivir, perspectiva que puede trasladarse en todos sus puntos también a los tiempos prerromanos. Al aplicar dichos enfoques al conocimiento de las comunidades protohistóricas andaluzas, se empiezan a ver diferencias étnicas y ambientes heterogéneos donde la arqueología tradicional sólo parecía observar un mundo homogéneo sustentado en la cultura ibérica. Mas, para percatarse de esas características distintas, deben usarse indicadores que aludan a los componentes animológicos de las diversas etnias, y no aspectos puramente materiales de sus respectivas tecnologías. Con ello, tal vez nuevos estudios eviten afirmaciones como la que, con cierta razón, sostiene que "la Arqueología carece de la capacidad de identificar a los pueblos" (Villar, 1991: 454).

La hipótesis aquí defendida deja evidentemente muchos cabos sueltos. Queda clara al menos la dualidad cultural de Andalucía en época prerromana y, en consecuencia, su carácter fronterizo. De alguna forma, estas diferencias deben tener sus raíces más hondas en los sustratos correspondientes de ambas mitades de la región. A gran escala, es decir, desde la perspectiva que nos permitiría distinguir conjuntos de pueblos, esa diversidad conduciría con el tiempo a la génesis de formaciones económicas y. sociales con límites que deben de entenderse más como amplios espacios de transición que como rígidas fronteras estatales (Castro y González, 1989: 10-15), sin perjuicio de que algunos asentamientos o conjuntos de ellos constituyeran, como se ha propuesto por ejemplo para el mundo vacceo (Sacristán, 1989: 80-81), auténticas civitates con plenos poderes sobre sus territorios y con unos pocos comportamientos políticos y administrativos propios de las sociedades organizadas en estados. En cualquier caso, las abundantes rencillas inter e intragrupales, fomentadas a veces por los ejércitos cartagineses y romanos para acceder más fácilmente a la conquista de la región, hacen improbable la identificación necesaria de etnias con formaciones estatales a la manera en que se ha defendido para la Bastetania por ejemplo (Aguayo y Salvatierra, 1987: 236), y aconsejan actuar en este terreno al menos con tanta prudencia como la usada para interpretar la ocupación protohistórica del sureste cordobés (Murillo y otros, 1989: 170-171).

Pero las bases reales a partir de las que se produjo esta dicotomía regional necesitan de un tratamiento más profundo. Para la parte oeste del país es posible admitir que sus cimientos comenzaron a consolidarse sobre todo a partir del Bronce Final. Para la zona oriental en cambio, el proceso de iberización parece producto de la convergencia de factores de muy distinta índole, entre los que deben citarse tanto el sustrato demográfico y cultural heredado al menos de la Edad del Bronce como el aporte del mundo ibérico desde el Sureste. En atención, además, a las correlaciones directas que se han establecido entre poblaciones biológicas y hablas (Cavalli-Sforza, 1991: 10), esta diversidad debió quedar reflejada paralelamente, antes desde luego de que el latín se convirtiera en lengua única para todas las gentes, en una relativa diferenciación dual de sus cargas genéticas.

Si se desciende a terrenos más concretos, todavía debería resolverse cómo encajar en este panorama -y sobre todo cómo detectarlos arqueológicamente- a los colonos que supuestamente llegaron a Tartes- 
sos con la intención de asentarse en su interior para explotar sus posibilidades económicas, a las poblaciones libiofenicias de las costas mediterráneas, a los Celtici de la Beturia, a los comerciantes fenicios de Cádiz, a los mercenarios celtibéricos convocados por los Turdetanos para luchar en sus filas, a los grupos cartagineses que por motivos bélicos -y en última instancia económicos- se adentraron en el Alto Guadalquivir, a los grupos púnicos o similares de las costas almerienses, a las primeras legiones y comunidades latinas establecidas en el territorio, etc., etc., etc. El reto para la arqueología es evidente: sería su cometido intentar al menos saber si puede o no distinguir los árboles en el conjunto del bosque, y dar así una respuesta clara, aunque sea negativa como de hecho se ha llevado a cabo ya con el armamento ibérico por ejemplo (Quesada 1989: 119), a los historiadores que quieran usar la documentación material para el estudio de cada uno de dichos grupos humanos y de sus correspondientes subdivisiones en unidades infraétnicas.

\section{BIBLIOGRAFIA}

ABAD, L. 1979: "Consideraciones en torno a Tartessos y el origen de la cultura ibérica", Archivo Español de Arqueología 52: 175-193.

AGUAYO, P. y SALVATIERRA, V. 1987: "El poblamiento ibérico en las altiplanicies granadinas", Iberos. Actas de las I Jornadas sobre el Mundo Ibérico / Jaén, 1985: 229-238. Jaén.

AGUAYO, P. y otros. 1985: "El yacimiento pre y protohistórico de Acinipo (Ronda, Málaga). Campaña de 1985", Anuario Arqueológico de Andalucía, 1985. Il, Actividades Sistemáticas: 294-304. Sevilla.

ALBELDA, J. 1923: "Bronzes de Huelva (Espagne)", Révue Archéologique, 5 série, XVIII: 222-226.

ALMAGRO, M. 1940: "El hallazgo de la Ría de Huelva y el final de la Edad del Bronce en el Occidente de Europa", Ampurias II: 85-143.

1975: "Depósito de bronces de la Ría de Huelva", en Huelva: Prehistoria y Antigüedad: 214-220. Madrid.

ALMAGRO GORBEA, M.J. 1973: Los Idolos del Bronce I Hispano (B.P.H. XII). Madrid.

ALMAGRO-GORBEA, M. 1982: "Tumbas de cámara y cajas funerarias ibéricas. Su interpretación socio-cultural y la delimitación del área cultural ibérica de los Bastetanos", En Homenaje a Conchita Fernández Chicarro: 249-257. Madrid.

1990: “Segunda Edad del Hierro", en Historia de España. 1, Desde la prehistoria hasta la conquista romana (siglo IIl a.C.): 511-583. Barcelona, Ed. Planeta.

ALVAREZ, J. 1952: "La falsa ecuación Massieni-Bastetani y los nombres en -tani". Archivo de Prehistoria Levantina III: 263-282.

ARCE, J. 1989: “Estrabón sobre la Bética”, Estudios sobre Urso: Colonia Iulia Genetiva: 213-222.

ARRIBAS, A. 1976: Los lberos. Barcelona.

ARTEAGA, O. 1985: "Excavaciones arqueológicas sistemáticas en el Cerro de los Alcores (Porcuna, Jaén). Informe preliminar sobre la campaña de 1985", Anuario Arqueológico de Andalucía, 1985. Il, Actividades Sistemáticas: 279-288. Sevilla.

AUBET, M.E. 1979: "Marfiles fenicios del Bajo Guadalquivir I, Cruz del Negro", Studia Archaeologica 52. Valladolid.

1980: "Marfiles fenicios del Bajo Guadalquivir II (Acebuchal y Alcantarilla)", Studia Archaeologica 63. Valladolid.

1981-82: "Marfiles fenicios del Bajo Guadalquivir III (Bencarrón, Santa Lucía y Setefilla)", Pyrenae 17-18: 231-279.

1982: "Los enterramientos bajo túmulo de Setefilla (Sevilla)", Huelva Arqueológica VI: 49-70.

BELEN. M. 1978: Las cerámicas a torno con decoración pintada en Andalucía (siglos VIII-VI a.C.). Madrid, Universidad Complutense, Tesis doctoral inédita.

e.p.: "Religiosidad funeraria en la necrópolis prerromana de Cádiz", Tabona. Homenaje a M. Pellicer. 
BELEN, M. y ESCACENA, J.L. e.p.a: "Las comunidades prerromanas de Andalucía occidental", I Congreso de Paletnología de la Península lbérica (Madrid, 1989).

e.p.b: "Las necrópolis ibéricas de Andalucía occidental", Congreso Internacional de Arqueología Ibérica: Las Necrópolis (Madrid, 1991). Madrid.

BELEN, M. y PEREIRA, J. 1985: "Cerámicas a torno con decoración pintada en Andalucía", Huelva Arqueológica VII: $307-360$.

BELEN, M. y otros. e.p.: "El mundo funerario del Bronce Final en la fachada atlántica de la Península Ibérica. I, Análisis de la documentación", Trabajos de Prehistoria.

BENDALA, M. 1979: "La etapa final de la cultura ibero-turdetana y el impacto romanizador", La Baja Epoca de la Cultura Ibérica: 33-48. Madrid.

1989: "La génesis de la estructura urbana en la España antigua", Cuadernos de Prehistoria y Arqueología de la Universidad Autónoma de Madrid 16: 127-147.

BENDALA, M. y CORZO, R. e.p.: "Paleoetnología de Andalucía occidental (Etnogeografía)", I Congreso de Paletnología de la Península Ibérica (Madrid, 1989).

BLANCO, A. 1963: "El ajuar de una tumba de Cástulo", Archivo Español de Arqueología XXXVI, n.o 107-108: 40-69.

1985: "Los nuevos bronces de Sancti Petri", Boletín de la Real Academia de la Historia CLXXXII, II: 207216.

BLAZQUEZ, J.M. 1975: Cástulo 1. (Acta Arqueológica Hispánica 8). Madrid. 1979: Cástulo II. (Excavaciones Arqueológicas en España 105). Madrid.

BLAZQUEZ, J.M. y FERNANDEZ URIEL, P. 1974: “Urna oretana en la muralla de Cástulo", Zephyrus XXV: 343-350.

BLAZQUEZ, J.M. y MOLINA, F. 1973: "La necrópolis ibérica de Los Patos, en la ciudada de Cástulo (Linares, Jaén)", XII Congreso Nacional de Arqueología: 639-656. Zaragoza.

BLAZQUEZ, J.M. y REMESAL, J. 1975: "Hallazgos de la necrópolis oreetana de Cástulo", XIII Congreso Nacional de Arqueología: 639-658. Zaragoza.

BLAZQUEZ, J.M. y otros. 1980: Historia de España Antigua. I, Protohistoria. Madrid.

BONSOR, G. 1899: Les colonies agricoles pré-romaines de la vallée du Bétis. París.

BOSCH, P. 1974a: "La prehistoria de los iberos y la etnología vasca", en Paletnología de la Península Ibérica. Barcelona.

1974b: "Los iberos", en Paletnología de la Península Ibérica: 1-50. Barcelona.

1974c: "Ibères, basques, celtes", en Paletnología de la Península Ibérica. Barcelona.

BRADLEY, R. 1990: The Passage of Arms. An archaeological analysis of prehistoric hoards and votive deposits. Cambridge.

BRADLEY, R. y GORDON, K. 1988: "Human skulls from the River Thames, their dating and significance", Antiquity 62: 503-509.

CARO, R. 1634: Antigüedades y Principado de la Ilustrissima Ciudad de Sevilla y Chorografia de su Convento Iuridico o Antigua Chancilleria. Sevilla.

CARO BAROJA, J. 1976: Los Pueblos de España, I. Madrid.

CARRIAZO, J. de M. 1980: Protohistoria de Sevilla. Sevilla.

CASTRO, P.V. y GONZALEZ, P. 1989: "El concepto de frontera: Implicaciones teóricas de la noción de territorio político", Fronteras. Arqueología Espacial 13 (Teruel, 1989): 7-18. Teruel.

CAVALLI-SFORZA, L.L. 1992: "Genes, pueblos y lenguas", Investigación y Ciencia 184 (Enero 1992): 4-11.

CORREA, J.A. 1989: "El origen de la escritura paleohispánica", Estudios sobre Urso. Colonia Iulia Genetiva: 281-302. Sevilla.

CUADRADO, E. 1954: "El problema ibérico en la cerámica exótica de barniz rojo", I Congreso Arqueológico del Marruecos Español: 236-251. Tertuán.

CHAPA, T. 1985: La Escultura Ibérica Zoomorfa. Madrid.

1990: "La escultura ibérica de Jaén en su contexto mediterráneo", en Escultura Ibérica en el Museo de Jaén: 43-51. Sevilla. 
1991: "La «Arqueología de la Muerte»: Planteamientos, problemas y resultados", Fons Mellaria. Cursos de Verano 1990: 13-38. Córdoba.

e.p.: "Cultural interaction between Punic Colonies and Iberian Land: the funerary evidence", The Firts International Conference in America on Iberian Archaeology: New Perspectives in Western Mediterranean Archaeology: Encounters, Transitions, Transformations (Tufts University, 1991).

CHAPA, T. y PEREIRA, J. e.p.: "Las etnias prerromanas del sureste: problemas de su comprobación arqueológica", Il Congreso de Historia de Andalucía (Córdoba, 1991).

CHAVES, F. y DE LA BANDERA, M.L. 1991: “Aspectos de la urbanística en Andalucía occidental en los s. VII-VI a.C. a la luz del yacimiento de Montemolín (Marchena, Sevilla)", Atti del II Congresso Internazionale di Studi Fenici e Punici II: 691-714. Roma.

DARVILL, T. 1987: Prehistoric Britain. London.

DE FRUTOS, G. 1991: Cartago y la política colonial. Los casos norteafricano e hispano. Sevilla.

DE HOZ, J. 1989: "El desarrollo de la escritura y las lenguas de la zona meridional", Tartessos. Arqueología Protohistórica del Bajo Guadalquivir: 523-587. Sabadell, Ed. Ausa.

1991: "Las lenguas célticas peninsulares", en Los Celtas en la Península Ibérica. Revista de Arqueología (n." especial): $36-41$.

DEL AMO, M. 1978: "El Castañuelo. Un poblado céltico en la provincia de Huelva", Huelva Arqueológica 4: 299-340.

DRAGADZE, T. 1980: “The place of «etnos» theory in Soviet Antrhopology", en Soviet and Western Antrhopology, por E. Gellner (ed.): 161-170. London.

ESCACENA, J.L. 1987a: "El poblamiento ibérico en el Bajo Guadalquivir", Iberos. Actas de las Primeras Jornadas sobre el Mundo Ibérico / Jaén, 1985: 273-298. Jaén.

1987: Cerámicas a torno pintadas andaluzas de la segunda Edad del Hierro. Edición en microfichas. Cádiz. 1989: "Los Turdetanos a la recuperación e identidad perdida", en Tartessos. Arqueología Protohistórica del Bajo Guadalquivir: 433-476. Sabadell, Ed. Ausa.

ESCACENA, J.L. y BELEN, M. 1991: "Sobre la cronología del horizonte fundacional de los asentamientos tartésicos", Cuadernos del Suroeste 2: 9-42.

e.p.: "Sobre las necrópolis turdetanas", Homenaje a F. Presedo. Sevilla.

FERNANDEZ JURADO, J. 1986: “Economía tartésica: minería y metalurgia", Huelva en su Historia. Miscelánea Histórica: 149-170. Sevilla.

1987a: "Tejada la Vieja: una ciudad protohistórica", HuelvaArqueológica IX.

1987b: "El poblamiento ibérico en Huelva", Iberos. I Jornadas sobre el Mundo Ibérico / Jaén, 1985: 315-326.

Jaén.

1989: "Influencia fenicia en la arquitectura tartésica", I-IV Jornadas de Arqueología Fenicio-Púnica (Ibiza 1986-89). Trabajos del Museo Arqueológico de Ibiza 24: 169-173.

1991: "Ciudades y fortificaciones turdetanas: problemas de interpretación”, Simposi Internacional d'Arqueologia Ibèrica. Fortificacions. La problemàtica de l'ibèric ple: (segles IV-III a.C.), (Manresa, 1990): 55-66. Manresa.

FERNANDEZ JURADO, J. y RUIZ MATA, D. 1985: "La metalurgia de la plata en época tartésica en Huelva", Pyrenae 21: 23-44.

GAMER-WALLERT, I. 1982: "Zwei Statuetten syro-ägyptischer Gottheiten von der Barra de Huelva", Madrider Mitteilungen 23: 46-61.

GONZALEZ, J. 1990: “La escultura ibérica de Cerrillo Blanco (Porcuna)", en Escultura Ibérica en el Museo de Jaén: 35-42. Sevilla.

GONZALEZ WAGNER, C. 1982: "Recensión de la obra Tartessos. Arqueología Protohistórica del Bajo Guadalquivir. En Spal 1.

1986a: "Tartessos y las tradiciones literarias", Rivista di Studi Fenici XIV,2: 201-228.

1986b: "Notas en torno a la aculturación en Tartessos", Gerión 4: 129-160.

GONZALEZ WAGNER, C. y ALVAR, J. 1989: "Fenicios en Occidente: la colonización agrícola", Rivista di Studi Fenici XVII, 1: 61-102. 
GORROCHATEGUI, J. 1985-86: "En torno a la clasificación del Lusitano", Veleia 2-3: 77-91

HARRIS, M. 1987: Caníbales y reyes. Los orígenes de las culturas. Madrid.

INIESTA, A. 1989: “Notas para la reconstrucción del área mastieno-bastetana en el Sureste peninsular”, Actas del XIX Congreso Nacional de Arqueología.

LIPINSKI, E. 1984: "Vestiges phéniciens d'Andalousie”, Orientalia Lovaniensia Periodica 15: 81-132.

LOPEZ PALOMO, L.A. 1980: La Cultura Ibérica del Valle Medio del Genil. Córdoba.

LUZON, J.M. 1990: "Sobre el origen oriental de las llamadas cajitas celtibéricas", II Congreso de Historia de Palencia, I: 319-325. Palencia.

MARIN, M.C. y BELEN, M.

1986-87: "Nuevos exvotos ibéricos de la provincia de Jaén", Anales de la Universidad de Cádiz III-IV: 79-106.

MARIN, M.C. y CORZO, R. 1991: "Escultura femenina entronizada en la necrópolis de Cádiz", Atti del II Congresso Internazionale di Studi Fenici e Punici, III: 1025-1038.

MCKERRELL, H. y TYLECOTE, R.F. 1972: "The working of copper-arsenic alloys in the Early Bronze Age and the effect on the determination of provenance", Proceedings of the Prehistoric Society 38: 209-218.

MOLINA, F. 1978: "Definición y sistematización del Bronce Tardío y Final en el Sudeste de la Península Ibérica", Cuadernos de Prehistoria de la Universidad de Granada 3: 159-232.

MONTILLA, S. y otros. 1989: "Análisis de una frontera durante el horizonte ibérico en la depresión PriegoAlcaudete”, Fronteras. Arqueología Espacial 13 (Teruel, 1989): 137-149. Teruel.

MURILLO, J.F. y otros. 1989: "Aproximación al estudio del poblamiento protohistórico en el sureste de Córdoba: unidades políticas, control del territorio y fronteras", Fronteras. Arqueología Espacial 13 (Teruel, 1989): 151-172. Teruel.

NEGUERUELA, I. 1990: Los monumentos escultóricos ibéricos del Cerrillo Blanco de Porcuna (Jaén). Madrid.

NICOLINI, G. 1977: Bronces Ibéricos. Barcelona.

NIETO, G. y otros. 1980: Oreto I (Excavaciones Arqueológicas en España 114). Madrid.

NOCETE, F. 1989: "El análisis de las relaciones Centro/Periferia en el Estado de la Primera Mitad del Segundo Milenio a.n.e. en las Campiñas del Alto Guadalquivir", Fronteras. Arqueología Espacial 13 (Teruel, 1989): 37-61. Teruel.

NUÑEZ, E. y J. MUÑOZ. 1988: "Excavación en la necrópolis del Cerro de las Balas. Ecija. Sevilla", Anuario Arqueológico de Andalucía 1988. III, Actividades de Urgencia: 429-433.

PASTOR, M. y otros. e.p.: "Paletnología de Andalucía oriental (etnogeografía)", l Congreso de Paletnología de la Península Ibérica (Madrid, 1989).

PELLICER, M. 1968: "Las primitivas cerámicas a torno pintadas hispanas", Archivo Español de Arqueología 41 : 60-90.

1969: "Las primeras cerámicas a torno pintadas andaluzas y sus problemas", Tartessos y sus problemas. Vo S.I.P.P. (Jerez, 1968). Barcelona.

1976-78: "Problemática general de los inicios de la iberización en Andalucía occidental", Ampurias 38-40: 322.

1979-80: "Ensayo de periodización y cronología tartesia y turdetana", Habis 10-11: 307-333.

PEREIRA, J. 1987: "Imitaciones ibéricas de cráteras áticas procedentes de Gor (Granada)"; XVIII Congreso Nacional de Arqueología: 701-711. Zaragoza.

1988a: La cerámiça pintada a torno en Andalucía entre los siglos VI y III a.d.C. Cuenca del Guadalquivir. Madrid.

1988b: "La cerámica ibérica de la cuenca del Guadalquivir, I. Propuesta de clasificación", Trabajos de Prehistoria 45: 143-173.

1989a: "La cerámica ibérica de la cuenca del Guadalquivir, II. Conclusiones", Trabajos de Prehistoria 46: 149-159.

1989b: "Necrópolis ibéricas andaluzas. Nuevas perspectivas en su valoración y estudio", Tartessos. Arqueología Protohistórica del Bajo Guadalquivir: 477-494. Sabadell, Ed. Ausa.

PEREIRA, J, y SANCHEZ, C. 1988: "Imitaciones ibéricas de vasos áticos en Andalucía", Mesa redonda sobre cerámicas griegas y helenísticas en la Península Ibérica: 87-100. Madrid. 
PRESEDO, F. 1973: “La Dama de Baza”, Trabajos de Prehistoria 30: 151-216.

1982: La Necrópolis de Baza (Excavaciones Arqueológicas en España 119). Madrid.

QUEROL, M.A. 1991: De los primeros seres humanos. Madrid.

QUESADA, F. 1989: “Consideraciones sobre el uso del armamento ibérico para la delimitación de unidades geopolíticas”, Fronteras. Arqueología Espacial 13 (Teruel, 1989): 111-120. Teruel.

RENFREW, C. 1990: Arqueología y lenguaje. La cuestión de los orígenes indoeuropeos. Barcelona.

RIIS, P.J. 1950: "La Estatuilla de alabastro de Galera", Notas del Seminario de Historia Primitiva del Hombre: 113-127.

RUIZ, A. e.p.: "Etnogénesis de las poblaciones prerromanas de Andalucía oriental", I Congreso de Paletnología de la Península Ibérica (Madrid, 1989).

RUIZ, A. y HORNOS, F. e.p.: "Las necrópolis ibéricas de Andalucía oriental”, Congreso Internacional de Arqueología Ibérica: Las Necrópolis (Madrid, 1991).

RUIZ, A. y MOLINOS, M. 1995: "Informe preliminar de la campaña de excavación sistemática de 1985 en el Cerro de la Plaza de Armas (Puente Tablas, Jaén)", Anuario Arqueológico de Andalucía 1985. II, Actividades sistemáticas: $345-352$.

1986: "Excavación arqueológica sistemática en Puente Tablas (Jaén)", Anuario Arqueológico de Andalucía 1986. II, Actividades sistemáticas: 401-407.

1988: "Informe de la campaña de 1988 en el cerro de la Plaza de Armas de Puente Tablas (Jaén)", Anuario Arqueológico de Andalucía 1988. II, Actividades sistemáticas: 179-184.

RUIZ, A. y otros. 1987: “El poblamiento ibérico en el Alto Guadalquivir”, Iberos. I Jornadas sobre el Mundo Ibérico / Jaén, 1985: 239-256. Jaén.

1991: "Fortificaciones ibéricas en la alta Andalucía", Simposi Internacional d'Arqueologia Ibèrica. Fortificacions. La problemàtica de l'ibèric ple: (segles IV-III a.C.), (Manresa, 1990): 109-124. Manresa.

RUIZ DELGADO, M.M. 1989: "Las necrópolis tartésicas: prestigio, poder y jerarquías”, Tartessos. Arqueología Protohistórica del Bajo Guadalquivir: 247-286. Sabadell, Ed. Ausa.

RUIZ-GALVEZ, M. 1982: "Nueva espada dragada en el río Ulla. Armas arrojadas a las aguas", Homenaje a Alfredo García Alén: 3-18. Pontevedra.

1983: "Espada procedente de la Ría de Larache en el Museo de Berlín Oeste", Homenaje al Prof. Martín Almagro Basch, II: 63-68. Madrid.

1984: La Península lbérica y sus relaciones con el círculo cultural atlántico. Madrid.

1991: "Songs of a wayfaring lad", Oxford Journal of Archaeology 10,3: 277-306.

RUIZ MATA, D. 1987: "La formación de la cultura turdetana en la Bahía de Cádiz a través del Castillo de Doña Blanca (Puerto de Santa María, Cádiz)", Iberos. Actas de las I Jornadas Arqueológicas sobre el Mundo Ibérico / Jaén, 1985: 299-314. Jaén.

RUIZ MATA, D. y PEREZ, C. 1989: "El túmulo 1 de la necrópolis de "Las Cumbres“ (Puerto de Santa María, Cádiz)”, Tartessos. Arqueología Protohistórica del Bajo Guadalquivir: 287-295. Sabadell, Ed. Ausa.

SACRISTAN, J.D. 1989: "Vacíos vacceos", Fronteras. Arqueología Espacial 13 (Teruel, 1989): 77-88. Teruel.

SCHULTEN, A. 1920: Hispania. Barcelona.

SIRET, L. 1890: Las primeras edades del metal en el sudeste de España. Barcelona.

TERRERO, J. 1991: Armas y objetos de bronce extraidos en los dragados del puerto de Huelva. Huelva.

TOVAR, A. 1985-86: "Lenguas y pueblos de la antigua Hispania: lo que sabemos de nuestros antepasados protohistóricos", Veleia 2-3: 15-34.

1987: "Estado actual de los estudios ibéricos", Archivo de Prehistoria Levantina XVII: 29-48.

UNTERMANN, J. 1984: "La lengua ibérica", Varia III: 249-272.

1985: "Lenguas y unidades políticas del suroeste hispánico en época prerromana", De Tartessos a Cervantes: 1-40. Köln.

1985-86: "Lusitanish, Keltiberish, Keltish", Veleia 2-3: 35-56.

VALLESPI, E. 1972: "Hipótesis de trabajo sobre el sustrato arqueológico de la romanización del País Vasco meridional (Alava y Navarra)", La Romanización del País Vasco (Segunda Semana de Antropología Vasca). Estudios de Deusto XX, n. 46: 241-250.

VILLAR, F. 1991: Los Indoeuropeos y los orígenes de Europa. Lenguaje e Historia. Madrid.

ISSN: 1133-4525 ISSN-e: 2255-3924

SPAL I (1992)

http://dx.doi.org/10.12795/spal.1992.i1.16 